ROCZNIKI TEOLOGICZNE

Tom LXVII, zeszyt $10-2020$

DOI: http://dx.doi.org/10.18290/rt206710-3

PIOTR GUZDEK

SYLWIA GUZDEK

\title{
PORONIENIE KLINICZNE JAKO NIEPOWODZENIE POŁOŻNICZE RODZICÓW - ASPEKT BIOMEDYCZNY
}

\author{
CLINICAL MISCARRIAGE AS OBSTETRIC FAILURE OF PARENTS \\ - BIOMEDICAL ASPECT
}

\begin{abstract}
Clinical miscarriage is pathology of diagnosed pregnancy before the 22nd week of prenatal development of a child weighing less than $500 \mathrm{~g}$. Every fourth woman experiences a procreational loss as a result of a clinical miscarriage. This type of obstetric failure is conditioned by multifactorial etiology of genetic, immunological, endocrine, morphological and anatomical, infectious, iatrogenic origins. The physiology of miscarriage allows making a typology of its clinical forms and on this basis distinguishing: threatening miscarriage, beginning miscarriage, ongoing miscarriage, complete miscarriage, incomplete miscarriage, retained miscarriage, cervical miscarriage, febrile miscarriage and septic miscarriage. The frequency of miscarriage indicates episodic and recurrent failures. The author of the study attempted to conceptualize clinical miscarriage and present its synthetic characteristics based on a review of the literature on the subject by employing the desk research method. As a result of the conducted analyzes the need to include the issue of reproductive losses in family education curricula and broadly understood prenatal education as a form of psychosocial prevention of obstetric failures and shaping positive social attitudes towards parents in mourning after miscarriage was pointed out.
\end{abstract}

Key words: clinical miscarriage; pregnancy loss; etiology; epidemiology; prenatal children.

PIOTR GUZDEK - mgr nauk o rodzinie (KUL), mgr dziennikarstwa i komunikacji społecznej (UPJPII), doktorant, Wydział Teologiczny, Uniwersytet Opolski, sekretarz zarządu Polskiego Stowarzyszenia Familiologicznego; e-mail: piotrguzdek@interia.pl; ORCID: https:/orcid.org/ 0000-0002-1727-8012.

SYLWIA GUZDEK - mgr finansów i bankowości, doktorant, Instytut Pedagogiki, Uniwersytet Jagiellońskiw Krakowie; e-mail: sylwia.guzdek@poczta.fm; ORCID: https://orcid.org/00000001-5455-8673. 


\section{WPROWADZENIE}

Psychospołeczne implikacje poronienia klinicznego korelują z poziomem wiedzy zarówno samych małżonków, jak również najbliższego otoczenia roniących rodziców w zakresie biomedycznej specyfiki tej stosunkowo częstej patologii ciąży. Kluczowym aspektem środowiskowego kontekstu straty prokreacyjnej jest ukształtowanie społecznego obrazu poronienia klinicznego jako bezpośrednio niezawinionej przez rodziców śmierci dziecka na wczesnych etapach rozwoju prenatalnego. Celem poniższego przedłożenia, mającego charakter pracy poglądowej, jest dokonanie konceptualizacji poronienia klinicznego poprzez: 1. określenie jego kryteriów definicyjnych właściwych dla praktyki klinicznej; 2. uchwycenie różnic pozwalających wyodrębnić poronienia subkliniczne od klinicznych w toku rozwoju ciąży; 3. charakterystykę częstotliwości strat ciąż na skutek poronienia klinicznego oraz 4. wskazanie możliwego spectrum przyczyn mogących determinować powikłanie ciąży poronieniem klinicznym. Dla realizacji przyjętego celu badawczego wykorzystano metodę desk research.

\section{KRYTERIA DEFINICYJNE PORONIENIA KLINICZNEGO}

Poronienie kliniczne jest patologią ciąży wewnątrzmacicznej skutkującą jej przedwczesnym zakończeniem w okresie niezdolności płodu do samodzielnego życia pozamacicznego ${ }^{1}$. Kryteria definicyjne tego powikłania położniczego mają charakter zarówno cenzusu czasowego, jak również odnoszą się do wagi ciała dziecka ${ }^{2}$. Kryterium czasowe definiuje poronienie jako niepowodzenie położnicze występujące przed dopełnieniem 22. tygodnia ciąży. Kryterium wagowe ustala miarę identyfikacyjną poronienia poniżej $500 \mathrm{~g}$ masy ciała embrionu lub płodu ${ }^{3}$. Tym samym poronienie jest uznawane za kliniczne, bowiem dotyczy zakończenia ciąży klinicznie rozpoznanej

${ }^{1}$ Por. T.G. Stovall, Poronienie i ciaża pozamaciczna, w: Ginekologia, t. 2, red. J.S. Berek, E. Novak, tłum. A. Czekierdowski, Wydawnictwo Medipage, Warszawa 2008, s. 663.

${ }^{2}$ Por. P. Szkodziak, T. Paszkowski, M. Paszkowski, T. Radomański, Poronienie, w: Położnictwo, t. 2. Medycyna matczyno-ptodowa, red. G.H. Bręborowicz, T. Paszkowski, Wydawnictwo Lekarskie PZWL, Warszawa 2012, s. 1.

${ }^{3}$ Por. M. Lewicka, M. Sulima, M. Pyć, M. Stawarz, Charakterystyka poronień i prawa przystugujace kobiecie po stracie dziecka, „Annales Academiae Medicae Stetinensis” 2013, nr 59, z. 1, s. 123. 
na podstawie dostępnych markerów biochemicznych i ultrasonograficznych bądź obserwacji specyficznych objawów ciążowych tak przez lekarza położnika, jak również przez samą kobietę. Występująca w następstwie powikłania przebiegu ciąży śmierć dziecka nie jest w żaden sposób celowo sprowokowana ani przez personel medyczny, ani przez jego matkę, lecz dochodzi do niej w naturalnym rezultacie oddziaływania na wczesną ciążę czynników patogennych, które najczęściej są warunkowane genetycznie lub chorobowo, nieco rzadziej generowane doznanymi urazami mechanicznymi ${ }^{4}$. Stąd poronienia kliniczne bywają także określane naturalnymi lub spontanicznymi. Toteż w żadnym wypadku nie należy utożsamiać ich z poronieniami sztucznymi, w których dziecko jest bezpośrednio uśmiercane w zamierzonej do osiągnięcia takiego celu procedurze medycznej: chirurgicznej lub farmakologicznej ${ }^{5}$. Poronienie kliniczne należy do grupy wczesnych niepowodzeń położniczych, wśród których można także wymienić ciążę ektopową czy ciążę bezzarodkową ${ }^{6}$. Do kategorii późnych niepowodzeń prokreacyjnych zalicza się natomiast letalną wadę wrodzoną, martwe urodzenie i poród przedwczesny $^{7}$.

\section{PORONIENIA SUBKLINICZNE VS PORONIENIE KLINICZNE}

Poronienia kliniczne odróżnia się od poronień subklinicznych. Te ostatnie zwane są również ciążami biochemicznymi ronionymi przez kobiety na bardzo wczesnych etapach rozwoju embrionalnego, kiedy nie jest jeszcze możliwe zdiagnozowanie rozwoju ciąży ${ }^{8}$. Przebieg procesu poronnego $\mathrm{w}$ tych przypadkach nie daje żadnych objawów albo mają one charakter niespecyficzny i przeważnie przyjmują postać opóźnionego krwawienia miesiączkowego w stosunku do terminu spodziewanej miesiączki ${ }^{9}$. Do zakończenia ciąży może dojść bezpośrednio po kariogamii albo w trakcie transportu

\footnotetext{
${ }^{4}$ Por. C.L. LAchelin, Poronienia, thum. A. Kurczuk-Powolny, Wydawnictwo Prószyński i S-ka, Warszawa 1998, s. 9.

${ }^{5}$ Por. M.S. GABRYŚ, Poronienie samoistne i sztuczne - ujęcie biologiczne, „Życie i Płodność” 2011, nr 1, s. 5-27.

${ }^{6}$ Por. B. ChazAn, Lekarz wobec poronienia, w: Poronienie. Zrozumieć rodziców po stracie, red. C. Klahs, Wydawnictwo W drodze, Poznań 2010, s. 131.

${ }^{7}$ Por. B. ChAZAN, Lekarz wobec poronienia, s. 131.

${ }^{8}$ Por. J. SkrzyPCZAK, Poronienie, w: Ciaża wysokiego ryzyka, red. G.H. Bręborowicz, wyd. 3, Ośrodek Wydawnictw Naukowych, Poznań 2010, s. 97.

${ }^{9}$ Por. W. ŚmiertKA, J. BoJ, Poronienie, „Nowa Klinika” 1999, nr 6 (12), s. 1231.
} 
embrionu do jamy macicy przez światło jajowodu poprzedzającego nidację ${ }^{10}$. Dużym ryzkiem obarczony jest skomplikowany proces implantacji. Wedle ostrożnych szacunków wskutek poronień subklinicznych traconych jest nawet $50-60 \%$ wszystkich poczętych dzieci ${ }^{11}$. Uwzględniając te dane łatwo wskazać, iż zaledwie 40\% ciąż udaje się w praktyce rozpoznać klinicznie, przy czym tylko około $30 \%$ dzieci urodzi się żywych, zaś pozostałe $10 \%$ umiera $\mathrm{w}$ wyniku poronienia klinicznego ${ }^{12}$. Niektóre statystyki podnoszą udział procentowy poronień klinicznych nawet do $15-20 \%$ wszystkich ciąż ${ }^{13}$. Istotnym kryterium różnicującym poronienia subkliniczne i kliniczne jest zatem diagnoza rozwoju ciąży ${ }^{14}$. Możliwości jej postawienia są jednak ściśle zdeterminowane warunkami kolejnych stadiów prenatalnego wzrostu dziecka. Identyfikacja gonadotropiny kosmówkowej $(\beta-h C G)$ za pomocą prostej próby ciążowej, jako podstawowego markera biochemicznego, jest możliwa powyżej 9. dnia od zapłodnienia ${ }^{15}$. Na ultrasonografii przezpochowej (TVS Transvaginal ultrasound) pierwsze cechy ultrasonograficzne ciąży są widoczne już w czwartym tygodniu jej rozwoju ${ }^{16}$. W co trzecim poronieniu klinicznym rozpoznaje się jedynie trofoblast po uprzedniej resorpcji zarodka ${ }^{17}$.

\section{EPIDEMIOLOGIA PORONIENIA KLINICZNEGO}

Częstotliwość występowania poronień klinicznych jest stosunkowo wysoka. Rocznie odnotowuje się w polskich szpitalach od 40 do 45 tysięcy poro-

\footnotetext{
${ }^{10}$ Por. B. ChazAn, M. TroszyŃski, Wczesne niepowodzenia prokreacji, w: Rozpoznawanie plodności. Materialy edukacyjno-dydaktyczne dla nauczycieli NPR, pracowników stużby zdrowia oraz zainteresowanych zdrowiem prokreacyjnym, red. M. Troszyński, wyd. 3, Bonami-Wydawnictwo Drukarnia, Warszawa-Poznań 2009, s. 48.

${ }^{11}$ Por. J. SkrzypCZaK, Poronienie, s. 97.

${ }^{12}$ Por. B. ChazAn, Nieudane rodzicielstwo - wspótczucie dla rodziców, szacunek dla ciała dziecka, w: Od bólu po stracie do nadziei życia. Pogrzeb dziecka poronionego, red. J. Dziedzic, P. Guzdek, Wydawnictwo UPJPII, Kraków 2013, s. 208.

${ }^{13}$ Por. A. Stupak, A. KWAŚNIEWSKA, Aktualne rekomendacje postępowania w poronieniu, „Wiadomości Lekarskie” 2015, nr 1 (68), s. 80.

${ }^{14}$ Por. P. GuzDEK, Rozpoznaj swoje dziecko we mnie... Rzecz o poronieniu samoistnym dziecka i jego pogrzebie, Wydawnictwo Scriptum, Kraków 2017, s. 61.

15 Por. A. StUPAK, A. KWAŚNIEWSKA, Aktualne rekomendacje postępowania w poronieniu, s. 80.

${ }^{16}$ Por. G. Johns, E. JauniauX, Rozwój wczesnej ciązy, w: Postępowanie w powikłaniach wczesnej ciąży. Podręcznik, red. T. Bourne, G. Condous, thum. J. Bartosiewicz, Wydawnictwo Medipage, Warszawa 2007, s. 12,17.

${ }^{17}$ Por. B. ChazAn, Lekarz wobec poronienia, s. 136.
} 
nień $^{18}$. W populacji ciężarnych kobiet blisko 1/4 doświadczyła w pierwszym trymestrze utraty pojedynczej ciąży ${ }^{19}$. Zachodzi ścisła zależność pomiędzy wiekiem ciążowym i ryzykiem poronienia: im wcześniejszy etap rozwoju prenatalnego, tym wyższy jest odsetek strat prokreacyjnych. Najwyższa częstotliwość dotyczy ciąż pierwszego trymestru. Do 80\% strat dochodzi przed dopełnieniem 12. tygodnia ${ }^{20}$. Z kolei po 14 . tygodniu ronionych jest zaledwie $2-3 \%$ ciąż $^{21}$. Strata jednej ciąży dla większości matek ma w ich historii położniczej charakter epizodyczny i nie komplikuje przebiegu dalszych ciąż. Zazwyczaj 90\% kobiet z epizodem pojedynczego poronienia donosi kolejną ciążę do terminu i rodzi żywe dziecko ${ }^{22}$. Ryzyko wystąpienia tej postaci niepowodzenia położniczego wiąże się również z wiekiem samych matek. Wiek niższy niż 25 lat oraz wyższy od 40 lat może się okazać czynnikiem patologizującym przebieg ciąży ${ }^{23}$. Nie bez znaczenia jest także późne ojcostwo, zwłaszcza powyżej 40. roku życia ${ }^{24}$. Ciąże wielopłodowe i pochodzące z procedury in vitro są częściej ronione niż ciąże jednopłodowe i te będące wynikiem naturalnego zapłodnienia ${ }^{25}$. Nie uwzględniając szczególnych sytuacji położniczych oraz liczby urodzonych dzieci, u każdej zdrowej kobiety ryzyko poronienia zawsze pozostaje na poziomie $5 \%{ }^{26}$.

\section{TYPOLOGIA PORONIENIA KLINICZNEGO}

Epidemiologia, etiologia i fizjologia poronienia klinicznego determinują jego wielopłaszczyznową typologię. Pierwsza klasyfikacja dotyczy granicz-

\footnotetext{
${ }^{18}$ Por. U. DudzIAK, Sytuacja rodziców doświadczajacych śmierci dziecka przed urodzeniem, w: Od bólu po stracie do nadziei życia. Pogrzeb dziecka poronionego, s. 181.

${ }^{19}$ Por. J. Skrzy PCZAK, Badania diagnostyczne u kobiet z wczesnymi utratami ciąz, w: Położnictwo, t. 4. Diagnostyka biofizyczna i biochemiczna w medycynie perinatalnej, red. G. Bręborowicz, M. Wielgoś, Wydawnictwo Lekarskie PZWL, Warszawa 2012, s. 365.

${ }^{20}$ Por. M. Lewicka, M. Sulima, M. PyĆ, B. Stawarz, Charakterystyka poronień i prawa przystugujace kobiecie po stracie ciąży, s. 124.

${ }^{21}$ Por. J. W. Dudenhausen, W. Pschyrembel, współpr. M. Obladen, Położnictwo praktyczne $i$ operacje polożnicze, tłum. K. Powolny, wyd. 6, Wydawnictwo Lekarskie PZWL, Warszawa 2010, s. 371 .

${ }^{22}$ Por. B. ChazAn, Lekarz wobec poronienia, s. 133.

${ }^{23}$ Por. J. SKrZYPCZAK, Poronienie, s. 97.

${ }^{24}$ Por. tamże.

${ }^{25}$ Por. G.C.L. LaChelin, Poronienia, s. 45.

${ }^{26}$ Por. B. Kwinecka-Dmitriew, M. Zakrzewska, A. Latos-Bieleńska, J. Skrzypczak, Częstość występowania aberracji chromosomowych $w$ materiale z poronien, ,Ginekologia Polska” 2010, nr 12 (81), s. 897.
} 
nego 12. tygodnia ciąży, przed upływem którego częstotliwość poronień jest najwyższa. Poronienia występujące do 12. tygodnia uznaje się za wczesne, natomiast te zachodzące między 12. a 22 tygodniem ciąży są traktowane jako poronienia późne $e^{27}$. We wczesnej ciąży dziecko nie uczestniczy w procesie poronnym, który na ogół ma charakter jednoetapowy i kończy się wydaleniem płodu wraz z całym pęcherzem płodowym ${ }^{28}$. Już powyżej 10. tygodnia proces poronienia przyjmuje postać dwufazową, przy czym w pierwszej fazie wydalane jest samo dziecko, natomiast w drugiej tylko fragmenty łożyska, ponieważ najczęściej nie dochodzi do pełnego opróżnienia jamy macicy $^{29}$. W drugim trymestrze, przy bardziej zaawansowanej ciąży, przebieg poronienia jest analogiczny do porodu ${ }^{30}$. Poronienia, których etiologia pozostaje niewyjaśniona pomimo podjęcia wieloaspektowej diagnostyki stanu zdrowia zarówno matki, jak i ojca oraz przeprowadzenia badania histopatologicznego i genetycznego tkanek płodowych, kwalifikuje się jako poronienia idiopatyczne $e^{31}$.

Utrata pojedynczej ciąży bez poprzedzających ją strat prokreacyjnych jest diagnozowana jako poronienie epizodyczne ${ }^{32}$. Poronienie przynajmniej trzech bezpośrednio po sobie następujących ciąż wypełnia znamiona nawykowych niepowodzeń i dlatego w praktyce klinicznej określa się je poronieniami nawracajacymi ${ }^{33}$. Jeżeli pomiędzy pojedynczymi stratami doszło do urodzenia żywego dziecka, wówczas dokonane poronienia identyfikuje się jako epizodyczne i nie nadaje się im statusu poronień nawykowych. W grupie poronień nawracających dodatkowo wyróżnia się poronienia pierwotne, które dotyczą straty wszystkich dotychczas poczętych dzieci, oraz poronienia wtórne odnoszące się do par, które choć raz urodziły zdrowe dziecko

${ }^{27}$ Por. U. DuDZIAK, Sytuacja rodziców doświadczających śmierci dziecka przed urodzeniem, s. 181.

${ }^{28}$ Por. J. SkrzypCZAK, Standardy postępowania $w$ nieprawidłowościach pierwszego trymestru ciąży, w: Poronienia nawracajace, red. J. Skrzypczak, Wydawnictwo Lekarskie PZWL, Warszawa 2011, s. 197.

${ }^{29}$ Por. J. W. Dudenhausen, W. Pschyrembel, współpr. M. OBladen, Położnictwo praktyczne i operacje położnicze, s. 374.

${ }^{30}$ Por. W. Śmiertka, J. Boj, Poronienie, s. 1232.

${ }^{31}$ Por. M. Lewicka, M. Sulima, M. Pyć, B. Stawarz, Charakterystyka poronień i prawa przystugujace kobiecie po stracie ciąży, s. 123.

${ }^{32}$ Por. D. Hofmann, Poronienie: zagrożenie i zaburzenia wczesnej cią̇y, przyczyny, rozpoznanie $i$ zapobieganie, tłum. J. Podgórski, Z. Tesarz, Państwowy Zakład Wydawnictw Lekarskich, Warszawa 1973, s. 22-23.

${ }^{33}$ Por. M. Michalak, D. Darmochwal-Kolarz, B. Leszczyńska-Gorzelak, J. OleszCZuK, Przyczyny, diagnostyka i leczenie poronień nawykowych - część II, „Ginekologia i Położnictwo" 2011, nr 3 (21), s. 9. 
przed trzema kolejno następującymi po urodzeniu żywym poronieniami dalszych ciąż $\dot{z}^{34}$.

Kolejne etapy procesu poronnego i sposób jego zakończenia stały się podstawą do wyróżnienia kilku możliwych postaci klinicznych tej patologii ciąży. Silne dolegliwości bólowe podbrzusza, nasilająca się czynność skurczowa macicy i liczne plamienia mogą wskazywać na stan zagrażający poronieniem diagnozowany jako poronienie zagrażajace. Jeżeli ujście szyjki macicy jest zamknięte, to istnieją szanse na utrzymanie ciąży po wdrożeniu odpowiedniego leczenia farmakologicznego i postępowania zachowawczego obejmującego całkowitą wstrzemięźliwość seksualną i reżim łóżkowy. Ten typ powikłania, jeśli nie dojdzie do wydalenia płodu, nie powinien powodować u dziecka żadnych wad i przeważanie większość ciąż jest prawidłowo donoszonych do terminu ${ }^{35}$.

Jeżeli proces poronienia postępuje dalej, to wówczas może przyjąć postać poronienia zaczynajacego się, które kolejno przechodzi w stan poronienia $w$ toku. W tej sytuacji klinicznej czynność skurczowa macicy znacząco się intensyfikuje. Szyjka macicy ulega stopniowemu skracaniu w części pochwowej, co prowadzi do rozwierania się jej ujścia wewnętrznego. Na tym etapie rozwoju procesu poronnego nie da się już zapobiec samoczynnemu wydaleniu płodu. Stwierdzenie w badaniu przedmiotowym obecności elementów jaja płodowego w pochwie, dowodzi wystąpienia poronienia $w$ toku, które zakończy się zupełnym lub niekompletnym opróżnieniem jamy macicy ${ }^{36}$.

Przy całkowitym oczyszczeniu macicy stwierdza się poronienie komplet$n e$. Ten typ poronień dotyczy, jak zaznaczono wyżej, wczesnych ciąż ronionych do 10. tygodnia, kiedy mechanizm poronienia jest jednofazowy. Jeżeli w dotychczasowym przebiegu ciąży nie wykonano badania ultrasonograficznego potwierdzającego rozwój ciąży wewnątrzmacicznej, zaleca się wdrożenie diagnostyki wykluczającej ciążę ektopową, zwłaszcza uwzględniającą seryjny pomiar stężenia gonadotropiny kosmówkowej. Przedłużające się

\footnotetext{
${ }^{34}$ Por. G. Jakiel, D. Robak-ChoŁubek, J. TkaczuK-WŁach, Poronienia samoistne, „Przegląd Menopauzalny" 2006, nr 3, s. 191.

${ }^{35}$ Por. E. Baszak, T. Paszkowski, S. Woźniak, P. Szkodziak, A. Torres, W. Zaleska, Poronienie samoistne, w: Patologia wczesnej ciaży, red. T. Paszkowski, IZT, Lublin 2004, s. 44; G.C.L. LACHELIN, Poronienia, s. 22.

${ }^{36}$ Por. J. W. Dudenhausen, W. Pschyrembel, współpr. M. Obladen, Połoznictwo praktyczne i operacje położnicze, s. 375; J. SKRZYPCZAK, T. PISARSKI, Poronienie, w: Położnictwo i ginekologia. Podręcznik dla studentów, red. T. Pisarski, Państwowy Zakład Wydawnictw Lekarskich, Warszawa 1991, s. 201; J. PIOTROWski, Pieleggniarstwo w położnictwie i ginekologii. Podręcznik dla studentów wydziałów pielęgniarskich akademii medycznych, wyd. 2, Państwowy Związek Wydawnictw Lekarskich, Warszawa 1984, s. 145.
} 
krwawienie może sugerować zaleganie w jamie macicy niewielkiej ilości tkanek ciążowych, uniemożliwiających obkurczanie się jej ścian. Uwidocznienie tkanek na obrazie USG upoważnia do przeprowadzenia zabiegu łyżeczkowania lub usunięcia ich przez podanie środków farmakologicznych stymulujących macicę do wypróżnienia. Nie zawsze możliwe jest przechwycenie embrionu lub płodu wraz z pozostałą częścią jaja płodowego. Nierzadko przebieg poronienia kompletnego udaremnia podjęcie diagnostyki genetycznej przyczyn jego wystąpienia oraz czyni organizację pochówku dziecka niemożliwą ze względu na bezpowrotną utratę tkanek płodowych ${ }^{37}$.

Tkanki, zabezpieczone $\mathrm{w}$ poronieniu niekompletnym, winny zostać poddane badaniu histopatologicznemu, które wykluczy ciążową chorobę trofoblastyczną. Choroba ta, niezdiagnozowana i nieleczona, może doprowadzić do rozwoju rozsianego nowotworu w organizmie matki. Leczenie poronienia niezupełnego przyjmuje trzy dopuszczalne formy. Wybór jednej z nich jest zależny od sytuacji klinicznej i decyzji matki. Niezwłoczne podjęcie postępowania terapeutycznego jest konieczne dla uniknięcia zakażenia wewnątrzmacicznego. Pierwsza forma leczenia przewiduje oczekiwanie na samoczynne opróżnienie macicy bez wdrażania terapii farmakologicznej. Tę formę leczenia można zastosować, gdy matka zachowuje ogólnie dobry stan zdrowia, a krwawienie $z$ dróg rodnych jest niewielkie. Przeciętny czas oczekiwania na spontaniczne wydalenie tkanek (tzw. resztek po poronieniu) z jamy macicy nie powinien przekroczyć 14 dni. Postępowanie wyczekujące stanowi jednak duże obciążenie psychiczne dla pacjentki. Również z tego względu, a także z powodu wskazań terapeutycznych (silne krwawienie, objawy zakażenia, dolegliwości bólowe podbrzusza, duża ilość zalegającego w macicy materiału) częściej stosuje się leczenie farmakologiczne i chirurgiczne. Przez leczenie chirurgiczne rozumie się łyżeczkowanie i rzadziej stosowaną w Polsce aspirację, oba zabiegi wykonywane są w znieczuleniu ogólnym w trybie chirurgii jednego dnia. Po opuszczeniu przez pacjentkę szpitala konieczne jest stosowanie środków zapobiegających laktacji ${ }^{38}$.

\footnotetext{
${ }^{37}$ Por. M. AlKatiB, Postępowanie wyczekujace w poronieniu, w: Postępowanie w powikłaniach wczesnej ciązy. Podręcznik, red. T. Bourne, G. Condous, thum. J. Bartosiewicz, Wydawnictwo Medipage, Warszawa 2007, s. 37-46; E. Norwitz, J. Schorge, Położnictwo i ginekologia w zarysie, red. nauk. thum. B. Chazan, Wydawnictwo Lekarskie PZWL, Warszawa 2006, s. 49-55.

${ }^{38}$ Postępowanie w przypadku straty wczesnej ciązy. Wytyczne Royal College of Obstetricians and Gynaecologists, „Medycyna Praktyczna - Ginekologia i Położnictwo” 2007, nr 2, s. 28; A. STUPAK, A. KWAŚNIEWSKA, Aktualne rekomendacje postępowania $w$ poronieniu, s. 82-83; G.C.L. LACHELIN, Poronienia, s. 30; E. Norwitz, J. SCHORGE, Polożnictwo i ginekologia w zarysie, s. 49.
} 
Na skutek procesu poronnego niekoniecznie musi dojść do wydalenia pło$\mathrm{du} \mathrm{z}$ ustroju matki. Unieruchomienie płodu wraz z pozostałymi produktami zapłodnienia $\mathrm{w}$ jamie macicy rozpoznaje się jako poronienie zatrzymane. Przyjmuje się, iż w przypadku tego typu poronień czas, jaki upłynął od faktycznej śmierci dziecka do ewentualnego wystąpienia jednoznacznie stwierdzalnych symptomów poronnych, wynosi przynajmniej tydzień. Martwy płód wraz z workiem owodniowym może przez wiele tygodni zalegać w jamie macicy. Znane są przypadki maceracji płodu. $Z$ tego powodu poronienie zatrzymane określa się również mianem ciąży obumarłej lub poronienia chybionego. Nierzadko pacjentki dowiadują się o wewnątrzmacicznej śmierci dziecka podczas rutynowej wizyty kontrolnej, nie spodziewając się uprzednio żadnych nieprawidłowości. Często bowiem poronienie manifestuje się w sposób niespecyficzny stopniowym zanikiem objawów ciążowych trudno zauważalnym przez matkę na jego początkowych etapach. Kobieta zgłasza się do lekarza dopiero po dłuższym czasie od obumarcia płodu z powodu wystąpienia dolegliwości bólowych w podbrzuszu oraz ciemnobrunatnych upławów. Badanie ginekologiczne ujawnia dużą rozbieżność pomiędzy przewidywanym stopniem rozwoju dziecka adekwatnym dla szacowanego wieku ciążowego a wielkością już obkurczającej się macicy. Seryjne oznaczanie stężenia gonadotropiny kosmówkowej potwierdzi systematyczny spadek wydzielania hormonu ciążowego. Przed podjęciem decyzji o usunięciu martwego płodu i łożyska z jamy macicy zaleca się co najmniej dwukrotne badanie ultrasonograficzne, z zachowaniem przynajmniej tygodniowego odstępu pomiędzy kolejnymi badaniami, jeżeli u pacjentki nie stwierdza się zaburzeń hemodynamicznych. Należy powziąć uzasadnione przypuszczenie, zwłaszcza gdy w dotychczasowym przebiegu ciąży nie wykonano ani razu diagnostyki ultrasonograficznej, iż błędnie określono wiek ciąży i dziecko pozostaje na wcześniejszym etapie niezaburzonego rozwoju, a ciąża faktycznie młodsza przebiega prawidłowo. Niezbędne jest zatem uzyskanie pewności, iż wiek ciąży został prawidłowo określony, a niewspółmierność ujawnianego na obrazie USG rozwoju dziecka do szacowanego tygodnia ciąży jednoznacznie wskazuje na poronienie chybione. Leczenie obumarłej ciąży, szczególnie w drugim trymestrze (w czwartym - piątym miesiącu), jest wyjątkowo uciążliwe dla matki, ponieważ musi ona urodzić martwe dziecko. Indukcja porodu jest dla rodziców wydarzeniem skrajnie traumatycznym. Niekorzystne ułożenie płodu może wymusić przeprowadzenie cesarskiego cięcia. Leczenie poronień zatrzymanych $w$ przypadku młodszych ciąż obejmuje 
postępowanie farmakologiczne zmierzające do stymulacji macicy do samoistnego opróżnienia bądź wykonanie zabiegu łyżeczkowania ${ }^{39}$.

Poronienie zatrzymane może przyjąć postać kliniczną poronienia szyjkowego diagnozowanego głównie u pierworódek. W mechanizmie tego poronienia płód oddziela się od endometrium w miejscu implantacji zazwyczaj usytuowanym w trzonie macicy i na skutek intensywnych skurczów mięśniówki macicy zostaje zepchnięty do kanału szyjki, która pozostaje jednak zamknięta. Bariera zaczopowanego ujścia szyjki macicy uniemożliwia wydalenie jaja płodowego do pochwy. Ewakuacja martwego płodu wymaga interwencji chirurgicznej ${ }^{40}$.

Powikłany przebieg omówionych wyżej typów poronienia klinicznego może doprowadzić do wystąpienia poronienia gorączkowego, które w ostrym przebiegu przechodzi w poronienie septyczne. Rozwój infekcji powoduje wysoką ciepłotę ciała przekraczającą $38^{\circ} \mathrm{C}$. Infekcja może mieć charakter miejscowy, czyli wewnątrzmaciczny, ale może także rozszerzyć się poza macicę na inne rejony jamy brzusznej. Jeśli zakażenie przeniknie do krwiobiegu matki, wówczas poronienie gorączkowe przyjmuje postać infekcji ogólnoustrojowej i jest diagnozowane jako poronienie septyczne stanowiące bezpośrednie zagrożenie życia matki z powodu ryzyka wystąpienia wielonarządowej niewydolności organizmu. Poronienia septyczne są obarczone wysokim wskaźnikiem śmiertelności. Postępowanie terapeutyczne polega na usunięciu z jamy macicy zakażonego jaja płodowego i wdrożenie antybiotykoterapii. W skrajnych przypadkach poronienie septyczne może zakończyć się amputacją narządu rodnego ${ }^{41}$.

Powikłania poronień mogą wystąpić także na skutek nieprawidłowości, do których dochodzi podczas łyżeczkowania. Interwencje chirurgiczne wiążą się z ryzykiem perforacji macicy. Wielokrotne i głębokie łyżeczkowanie może prowadzić do rozwoju zespołu pourazowych zrostów wewnątrzmacicznych. Stosunkowo rzadko dochodzi do powikłań anestezjologicznych ${ }^{42}$.

${ }^{39}$ Por. S.R. GoldsteIn, Diagnostyka poronienia, w: Postepowanie w powikłaniach wczesnej ciązy. Podręcznik, red. T. Bourne, G. Condous, tłum. J. Bartosiewicz, Wydawnictwo Medipage, Warszawa 2007, s. 28; G.C.L. Lachelin, Poronienia, s. 32; W. ŚmiertKa, J. BoJ, Poronienie, s. 1232; J. SKRZYPCZAK, T. PISARSKI, Poronienie, s. 201-202.

${ }^{40}$ Por. J. Skrzypczak, T. PisArski, Poronienie, s. 201-202.

${ }^{41}$ Por. T. Radomański, T. Paszkowski, W. Wrona, Poronienie septyczne, w: Patologia wczesnej ciąży, red. T. Paszkowski, IZT, Lublin 2004, s. 101-104.

${ }^{42}$ Por. E. Baszak, T. Paszkowski, S. Woźniak, P. Szkodziak, A. Torres, W. Zaleska, Poronienie samoistne, s. 50. 


\section{ETIOPATOGENEZA PORONIENIA KLINICZNEGO}

Przyczyny potencjalnie odpowiedzialne za epizod pierwszego poronienia niekoniecznie muszą być tożsame z czynnikami patogennymi drugiej ciąży, choć nie można wykluczyć dopuszczalnego związku między nimi. Standardowe badania diagnostyczne par z doświadczeniem co najmniej jednego poronienia przeprowadza się $\mathrm{w}$ trzech podstawowych kategoriach: anatomicznej, genetycznej i hormonalnej ${ }^{43}$. Pełna profilaktyka dalszych niepowodzeń położniczych powinna jednak objąć także badania zmierzające do wykluczenia ewentualnych zaburzeń immunologicznych, metabolicznych czy endokrynologicznych oraz wdrożenia adekwatnego leczenia wcześniej wykrytych chorób przewlekłych i zakażeń ${ }^{44}$. Stosunkowo rzadko lekarze decydują się na diagnostykę etiopatogenezy poronień występujących u danej pacjentki po pierwszej stracie. W praktyce klinicznej dąży się do kompleksowej identyfikacji przyczyn poronień dopiero po trzech bezpośrednio następujących po sobie stratach prokreacyjnych, a więc $\mathrm{w}$ przypadku stwierdzenia poronień nawracających ${ }^{45}$.

Pojedyncze poronienie jest prawdopodobnie zdeterminowane wieloczynnikową etiologiąa ${ }^{46}$. Przyczyny poronień mogą mieć pochodzenie matczyne lub ojcowskie, płodowe i łożyskowe bądź środowiskowe ${ }^{47}$. Udział procentowy poszczególnych źródeł potencjalnych zaburzeń jest szacowany na 50-60\% po stronie dziecka i łożyska, dalsze $20-30 \%$ po stronie matki oraz na względnie niewielki zakres procentowy czynników ojcowskich i zewnątrzpochodnych $^{48}$. Poronieniom, dokonanym $\mathrm{w}$ pierwszym trymestrze, przypisuje się etiologię genetyczną, z kolei straty drugiego trymestru są wiązane głównie $\mathrm{z}$ wadami anatomicznymi lub morfologicznymi macicy ${ }^{49}$.

\footnotetext{
${ }^{43}$ Por. J. SkrzypCZAK, Poronienie, s. 97.

${ }^{44}$ Por. tamże.

${ }^{45}$ Rekomendacje Polskiego Towarzystwa Ginekologicznego w zakresie wybranych patologii wczesnej ciązy oraz postępowania w ciązy po zaptodnieniu in vitro, „Przegląd Menopauzalny” 2004, nr 6, s. 8-12.

${ }^{46}$ J. SiKorA, I. BAKON, T. DemBNICKI, Znaczenie czynników infekcyjnych w poronieniach i porodzie przedwczesnym, „Ginekologia i Położnictwo” 2011, nr 2 (20), s. 37.

${ }^{47}$ Por. M. Bielecki, M. Łazewska, M. Jóźwik, Poronienie, w: Położnictwo i ginekologia. Podręcznik dla studentów, red. S. Soszka, Wydawnictwo Lekarskie PZWL, Warszawa 1988, s. 122.

${ }^{48}$ Por. M. JóźwIK, A. ŚLEDZIEwsKi, Powikłania poronień samoistnych i sztucznych, w: Powikłania poronień samoistnych i sztucznych, Wydawnictwo Lekarskie PZWL, Warszawa 2002, s. 338.

${ }^{49}$ Por. D. HofmanN, Poronienie: zagrożenie i zaburzenia wczesnej cią̇y, przyczyny, rozpoznanie i zapobieganie, s. 167.
} 
Poronienia warunkowane genetycznie dominują do 12. tygodnia ciąży. Zdefektowany kariotyp embrionu może być wynikiem nieprawidłowej gametogenezy jednego lub obojga rodziców, jak również zaburzeń samego procesu zapłodnienia bądź anomalii podziałów mitotycznych zygoty. W znacznej liczbie diagnozowanych par nie rozpoznaje się w rodzinach aberracji genetycznych. Tym samym wady, odpowiedzialne za dokonane poronienia, powstały $\mathrm{w}$ tych przypadkach de novo. W grupie najczęściej stwierdzanych wad genotypu embrionu wyróżnia się anomalie liczbowe (ok. 86\%) przyjmujące postać aneuploidii i poliploidii oraz anomalie strukturalne (ok. 6\%) $\mathrm{w}$ formie inwersji, translokacji, delecji i duplikacji dowolnych ramion chromosomów. Dominują jednak aneuploidie o typie trisomii chromosomów płciowych oraz chromosomów autosomalnych odpowiedzialne chociażby za zespół Downa (21. pary), zespół Edwardsa (18. pary) czy zespół Pataua (13. pary). $\mathrm{Z}$ tym jednak zastrzeżeniem, iż wymienione zespoły diagnozowane są także u dzieci żywo urodzonych. Płody obciążone trisomiami autosomalnymi innych par chromosomów najczęściej ulegają poronieniu na wczesnych etapach ciąży. Diagnostyka potencjalnych wad genetycznych płodu wzbudza kontrowersje etyczne, jeśli generuje wysokie ryzyko dla dziecka lub jest podejmowana ze względów eugenicznych. Podobnie wątpliwości etyczne rodzą proponowane sposoby leczenia par o obciążonym kariotypie. Przy nieprawidłowym kariotypie ojca literatura zaleca inseminację heterologiczną, z kolei w przypadkach anomalii matczynego kariotypu sugeruje zapłodnienie oocyta dawczyni w procedurze in vitro. Poza przyczynami genetycznymi poronień, identyfikowanymi po stronie ojca, mało poznane są inne patogeny pochodzenia ojcowskiego ${ }^{50}$.

Anomalie żeńskiego układu rozrodczego determinują patogenezę matczynych czynników poronień klinicznych o charakterze anatomicznym lub morfologicznym. Zaburzenia te są diagnozowane jako wrodzone anomalie morfologiczne macicy lub dysfunkcje czynnościowe nabyte wskutek dotychczasowych interwencji chirurgicznych przeprowadzanych w obrębie narządu. Wady wro-

${ }^{50}$ Por. D. Towner, Implikacje genetyczne utraty ciaży, w: Położnictwo, red. D.R. Mishell, P.F. Brenner, thum. B. Kamiński, wyd. 1, Wydawnictwo Alfa-Medica Press, Bielsko-Biała 1995, s. 430-436; T. Ferenc, W. Bratkowska, M. PacholczyK, L. Jakubowski, Zespoly aberracji chromosomowych, w: Genetyka medyczna. Podręcznik dla studentów, red. G. Drewa, T. Ferenc, Wydawnictwo Elsevier Urban \& Partner, Wrocław 2011, s. 479-481; T. FerEnc, H. KozŁowsKA, W. BRATKOwsKA, Zespoty aberracji chromosomowych, w: Podstawy genetyki dla studentów i lekarzy, red. G. Drewa, T. Ferenc, wyd. 2, Wydawnictwo Medyczne Urban \& Partner, Wrocław 2003, s. 363-368; E. PASSARGE. Genetyka. Ilustrowany przewodnik, Wydawnictwo Lekarskie PZWL, Warszawa 2004, s. 400; J.A. JAKOWICKI, Genetyczne przyczyny utraty wczesnej ciąży, „Postępy Biologii Komórki” 2001, supl. nr 18, s. 25-32. 
dzone macicy pozostają dominującym rozpoznaniem w poronieniach warunkowanych nieprawidłowościami układu rozrodczego matki, co w głównej mierze dotyczy strat prokreacyjnych drugiego trymestru ciąży. W tej grupie anomalii diagnozuje się najczęściej wady rozwojowe w postaci macicy przegrodzonej, macicy dwurożnej, macicy podwójnej czy macicy łukowatej. Z kolei zrosty wewnątrzmaciczne, gruczolistość endometrium, mięśniaki i niewydolność szyjki powstają następczo i należą do kategorii wad nabytych macicy. Wskazane schorzenia można również uporządkować wedle typologii wyróżniającej anomalie trzonu macicy i jej szyjki. Identyfikacja aberracji morfologiczno-anatomicznych narządu, zwłaszcza wad wrodzonych, jest trudna $\mathrm{w}$ okresie prekoncepcyjnym, ponieważ często nie manifestują one objawów specyficznych, z tego względu w wielu przypadkach pozostają nierozpoznane przed wystąienieniem poronienia ${ }^{51}$.

Za patogenezę wczesnych strat prokreacyjnych mogą również odpowiadać schorzenia endokrynologiczne i defekty immunologiczne. Uwzględnienie ich patologicznego wpływu na przebieg ciąży jest szczególnie zasadne przy poronieniach nawracających. Akceptacja przez system immunologiczny matki rozwijającego się embrionu wymaga poprawnej interakcji wielu mechanizmów adaptacyjnych, przebiegających pomiędzy ustrojem kobiety, zarodkiem i łożyskiem. Matczyny system immunologiczny rozpoznaje bowiem embrion jako tkankę obcą. Mechanizmy adaptacyjne zmierzają do udaremnienia odrzucenia alloprzeszczepu płodowo-łożyskowego poprzez uzyskanie dominacji odpowiedzi humoralnej typu Th2 układu odpornościowego matki nad komórkową typu Th1 na antygeny pochodzenia ojcowskiego, które embrion $\mathrm{w}$ sobie posiada. Determinacja immunologicznej reakcji ochronnej dziecka jest warunkowana odpowiednim zakresem rozbieżności antygenowej między matką i ojcem. Niewłaściwy przebieg mechanizmów adaptacyjnych systemu immunologicznego matki skutkuje poronieniem. Anomalie mogą mieć charakter nieprawidłowości alloimmunologicznych wymierzonych przeciwko antygenom płodowym pochodzenia ojcowskiego oraz aberracji autoimmunologicznych skierowanych przeciwko antygenom matczynym. Około $12 \%$ poronień nawracających jest konsekwencją zaburzeń endokrynologicznych matki. Do patogennych czynników sprawczych zalicza się niedomogę lutealną udaremniającą utrzymanie ciąży po przejęciu przez trofoblast

\footnotetext{
${ }^{51}$ Por. M. Gruszka, J. WilczyŃSKi, D. NowaKowsKa, Częstość występowania wad macicy i ich wpływ na płodność, „Ginekologia Polska” 2012, nr 7(83), s. 518; C.R. JASLOw, Uterine factors, „Obstetrics and Gynecology Clinics of North America” 2014, nr 1(41), s. 57-86; M. MicHALaK, D. Darmochwal-Kolarz, B. LeszczyńSKa-GorzelaK, J. OleszczuK, Przyczyny, diagnostyka i leczenie poronień nawykowych - część I, „Ginekologia i Położnictwo” 2011, nr 1(19), s. 17-20.
} 
zadań ciałka żółtego pomiędzy 8. a 11. tygodniem. Nieprawidłowości endokrynologiczne często występują we wzajemnych sprzężeniach, dlatego hiperinsulinemii może towarzyszyć hiperprolaktynemia bądź rozwój zespołu policystycznych jajników. W profilaktyce poronień nawykowych nie można także zaniedbać uprzedniego zdiagnozowania i właściwego leczenia cukrzycy (zwłaszcza typu 1) oraz schorzeń gruczołu tarczycowego jako endokrynologicznych chorób układowych matki ${ }^{52}$.

Stosunkowo mniej uwagi od dotychczas omówionych faktorów patogennych poświęca się infekcjom wewnątrzmacicznym w toku ciąży, zarówno zakażeniom bakteryjnym (kiła, chlamydioza, waginoza bakteryjna), jak również wirusowym, grzybiczym czy pierwotniakowym, których transmisja dokonuje się na drodze seksualnej. Matki przejawiają większą świadomość negatywnego wpływu na rozwój prenatalny dziecka infekcji przenoszonych drogą pozapłciową określanych mianem zespołu TORCH - toksoplazmozy, cytomegalii i różyczki, wirusa opryszczki i parowirusa B19. Literatura nie jest zgodna co do faktycznego ryzyka chorób grypowych w ciąży i roli otyłości w niepowodzeniach położniczych. Należy przyjąć, iż każda ogólnoustrojowa choroba matki, zwłaszcza o charakterze przewlekłym, jeśli upośledza działanie poszczególnych układów, jest potencjalnym czynnikiem strat prokreacyjnych. Potwierdzono również zależność pomiędzy doświadczaniem długotrwałego napięcia emocjonalnego i silnych reakcji afektywnych, a wyższym odsetkiem poronień epizodycznych. Nie kwestionuje się także poronnego działania cytostatyków, leków przeciwzakrzepowych, antymetabolitów i antagonistów kwasu foliowego. Ciężarna nie powinna przyjmować żadnych środków farmakologicznych bez uzgodnienia z lekarzem prowadzącym. Znaczna liczba mężczyzn i kobiet bagatelizuje wpływ nikotynizmu na możliwość wystąpienia niedotlenienia płodu oraz patogennych skutków spożywania alkoholu w okresie prekoncepcyjnym dla prawidłowego przebiegu spermatogenezy i oogenezy ${ }^{53}$.

${ }^{52}$ Por. A. Malinowski, J.R. WilczyŃSKi, Poronienia nawykowe, w: Patologia wczesnej ciąży, red. T. Paszkowski, IZT, Lublin 2004, s. 67-100; A. MALINOWSKI, J.R. WILCZYŃSKI, Immunologiczne mechanizmy utrzymania ciąży, „Ginekologia Praktyczna” 2003, nr 4(11), s. 47-56; A. MALINOwSKI, M. RADWAN, Diagnostyka immunologiczna w poronieniach nawykowych: algorytm postepowania diagnostyczno-leczniczego z wykorzystaniem wyników badań wtasnych, „Perinatologia, Neonatologia i Ginekologia” 2011, nr 1(4), s. 27-36; T. Opala, J. WoźNiaK, P. RZYMSKi, K. ChMAJ-WierzCHOWSKA, U. WINCONEK-OBERC, M. WILCZAK, Rola czynników immunologicznych w poronieniach nawykowych, „Ginekologia Polska” 2011, nr 5(11), s. 2-4; A. SiLvA, L. MiLIO, Schorzenia endokrynologiczne w ciązy, w: Podręcznik ginekologii i położnictwa Johns Hopkins, red. K.B. Fortner, L.M. Szymanski, H.E. Fox, E.E. Wallach, Wydawnictwo MediPage, Warszawa 2012, s. 225-240.

${ }^{53}$ Por. M. MichalaK, D. Darmochwat-Kolarz, B. LeszczyŃSKa-GorzelaK, J. OleszczuK, Przyczyny, diagnostyka i leczenie poronień nawykowych - część II, s. 9-26; J. SIKORA, I. BAKON, 


\section{ZDROWIENIE PO PORONIENIU KLINICZNYM}

Rekonwalescencja matek po niepowikłanym poronieniu na płaszczyźnie fizjologicznej przebiega stosunkowo szybko. W niespełna dwa miesiące macica powraca do stanu fizjologicznego sprzed ciąży. Starania o poczęcie kolejnego dziecka można podjąć po upływie 2-3 miesięcy od niepowodzenia położniczego. Przy podejmowaniu nowych decyzji prokreacyjnych niezbędne jest uwzględnienie pozasomatycznych - psychospołecznych i duchowych - konsekwencji poronień, odnoszących się do zdrowia psychicznego i duchowego rodziców, więzi małżeńskiej i rodzinnej. Osiągnięcie pełnej równowagi psychoduchowej przez dopełnienie procesu zdrowienia na wszystkich płaszczyznach życia osobowego, a więc nie tylko biomedycznej, jest podstawowym warunkiem opieki prekoncepcyjnej realizowanej przed poczęciem kolejnego dziecka. Profilaktyka powtórnych start prokreacyjnych wymaga diagnostyki etiopatogenezy już dokonanych poronieńn ${ }^{54}$. Jest to zadanie niezwykle trudne. Znacznej liczby poronień nie sposób przewidzieć ani zapobiec ich wystąpieniu ${ }^{55}$.

\section{PODSUMOWANIE}

Poronienie kliniczne dziecka jest przeważnie wydarzeniem niespodziewanym. Rodzice, zmagający się z nim po raz pierwszy, bardzo często nie dysponują wiedzą o jego fizjologii, epidemiologii i etiologii. Brak zrozumienia biomedycznej specyfiki tej patologii ciąży, jako bezpośrednio niezawinionej straty prokreacyjnej, negatywnie wpływa na sposób przepracowania przez rodziców psychologicznych i duchowych następstw prenatalnej śmierci dziecka. Niezwykle często wiąże się to $\mathrm{z}$ rozwojem nieuzasadnionego poczucia winy za dokonane poronienie pomimo obiektywnego faktu jego wieloczynnikowej etiologii. Częstotliwość poronień spontanicznych w pełni uzasadnia

T. DEMBNICKI, Znaczenie czynników infekcyjnych w poronieniach i porodzie przedwczesnym, s. 3546; J. SIKORA, Znaczenie czynników mikrobiologicznych $w$ poronieniach i porodzie przedwczesnym - standard postępowania diagnostyczno-leczniczego, „Perinatologia, Neonatologia i Ginekologia” 2011, nr 1(4), s. 37-43; E. SZAŁEK, E. GRZEŚKOWIAK, Bezpieczeństwo farmakoterapii w okresie ciąży, „Farmacja Współczesna” 2008, nr 1, s. 109-115.

${ }^{54}$ Por. M. Keirse, B. Spitz, A. VAndermeulen, Jak sobie radzić z poronieniem, thum. M. Wężkowska, Polskie Wydawnictwo Encyklopedyczne, Radom 2007, s. 58-59; A. STONEHOUSE, B. SuTHerland, Po poronieniu, Państwowy Zakład Wydawnictw Lekarskich, Warszawa 1992, s. 24-28.

${ }^{55}$ Por. B. CHAZAN, Nieudane rodzicielstwo - współczucie dla rodziców, szacunek dla ciała dziecka, s. 208. 
wprowadzenie do programu nauczania przedmiotu wychowanie do życia w rodzinie treści kształcenia, które wyposażą przyszłych rodziców w wiedzę umożliwiającą im konstruktywne przeżycie procesu żałoby po poronieniu klinicznym dziecka. Wiedza biomedyczna, uzupełniona zagadnieniami szczegółowo odnoszącymi się do psychospołecznych, etyczno-aksjologicznych i religijno-prawnych implikacji poronienia naturalnego, pozwoli także na formowanie właściwych postaw osób towarzyszących roniącym małżonkom. Istotnym zadaniem metodycznym, wymagającym adekwatnych środków dydaktycznych, jest zatem wypracowanie kompetencji przepracowania poronienia z pozycji zarówno rodzica doświadczającego straty prokreacyjnej, jak również osoby odpowiedzialnej za udzielenie roniącym małżonkom wsparcia społecznego.

Równocześnie należy podkreślić, iż dostarczenie nazbyt szczegółowej wiedzy o fizjologii i etiologii poronień klinicznych może okazać się szkodliwe i przynieść odwrotne skutki od zamierzonych. Zamiast skłaniać do podjęcia działań profilaktycznych, które od strony biomedycznej przygotują małżonków do poczęcia dziecka, wiedza ta może utrudnić prawidłowy przebieg ciąży przez wyższy poziom niepokoju i lęku przed potencjalnymi powikłaniami, a w konsekwencji zahamować rozwój przywiązania rodzicielskiego do dziecka prenatalnego. Konieczne jest znalezienie właściwej miary pomiędzy profilaktyką powikłań położniczych i kształtowaniem pozytywnych postaw rodzicielskich ukierunkowanych w pierwszej kolejności na afirmację poczętego dziecka bez nadmiernej koncentracji na możliwym ryzyku niepowodzeń położniczych. Wymaga to właściwego doboru treści kształcenia i odpowiedniego ukierunkowania przekazu dydaktycznego przez nauczycieli wychowania do życia w rodzinie. Jest to zadanie wymagające także zindywidualizowanej opieki prekoncepcyjnej i położniczej, którą winni zostać objęci oboje rodzice przez lekarza położnika uwzględniającego nie tylko fizjologiczne, ale również psychospołeczne i aksjologiczno-duchowe aspekty prokreacji.

\section{BIBLIOGRAFIA}

AlkatiB M., Postępowanie wyczekujace $w$ poronieniu, w: Postępowanie w powikłaniach wczesnej ciaży. Podręcznik, red. T. Bourne, G. Condous, thum. J. Bartosiewicz, Wydawnictwo Medipage, Warszawa 2007, s. 37-46.

Baszak E., Paszkowski T., Woźniak S., Szkodziak P., Torres A., Zaleska W., Poronienie samoistne, w: Patologia wczesnej ciąży, red. T. Paszkowski, IZT, Lublin 2004, s. 39-57. 
Bielecki M., Łazewska M., JóźwIK M., Poronienie, w: Położnictwo i ginekologia. Podręcznik dla studentów, red. S. Soszka, Wydawnictwo Lekarskie PZWL, Warszawa 1988, s. 121-127.

ChaZAn B., Lekarz wobec poronienia, w: Poronienie. Zrozumieć rodziców po stracie, red. C. Klahs, Wydawnictwo W drodze, Poznań 2010, s. 131-144.

Chazan B., Nieudane rodzicielstwo - wspótczucie dla rodziców, szacunek dla ciała dziecka, w: Od bólu po stracie do nadziei życia. Pogrzeb dziecka poronionego, red. J. Dziedzic, P. Guzdek, Wydawnictwo UPJPII, Kraków 2013, s. 207-2014.

ChaZAn B., Troszyński M., Wczesne niepowodzenia prokreacji, w: Rozpoznawanie płodności. Materiaty edukacyjno-dydaktyczne dla nauczycieli NPR, pracowników slużby zdrowia oraz zainteresowanych zdrowiem prokreacyjnym, red. M. Troszyński, wyd. 3, Bonami-Wydawnictwo Drukarnia, Warszawa-Poznań 2009, s. 48-52.

Dudenhausen J.W., Pschyrembel W., współpr. M. Obladen, Położnictwo praktyczne i operacje połoznicze, thum. K. Powolny, wyd. 6, Wydawnictwo Lekarskie PZWL, Warszawa 2010.

DuDZIAK U., Sytuacja rodziców doświadczajacych śmierci dziecka przed urodzeniem, w: Od bólu po stracie do nadziei życia. Pogrzeb dziecka poronionego, red. J. Dziedzic, P. Guzdek, Wydawnictwo UPJPII, Kraków 2013, s. 175-198.

Ferenc T., Bratkowska W., Pacholczyk M., Jakubowski L., Zespoly aberracji chromosomowych, w: Genetyka medyczna. Podręcznik dla studentów, red. G. Drewa, T. Ferenc, Wydawnictwo Elsevier Urban \& Partner, Wrocław 2011, s. 477-511.

Ferenc T., KozŁowsKa H., BRATKOwsKa W., Zespoly aberracji chromosomowych, w: Podstawy genetyki dla studentów i lekarzy, red. G. Drewa, T. Ferenc, wyd. 2, Wydawnictwo Medyczne Urban \& Partner, Wrocław 2003, s. 361-385.

Gabryś M.S., Poronienie samoistne i sztuczne - ujęcie biologiczne, „Życie i Płodność” 2011, nr 1, s. 5-27.

GoldsteIn S.R., Diagnostyka poronienia, w: Postępowanie w powikłaniach wczesnej ciąży. Podręcznik, red. T. Bourne, G. Condous, thum. J. Bartosiewicz, Wydawnictwo Medipage, Warszawa 2007, s. 27-35.

Gruszka M., WilCZyŃSKi J., NowAKOwSKa D., Częstość występowania wad macicy i ich wplyw na płodność, „Ginekologia Polska” 2012, nr 7 (83), s. 517-521.

GuZDeK P., Rozpoznaj swoje dziecko we mnie... Rzecz o poronieniu samoistnym dziecka i jego pogrzebie, Wydawnictwo Scriptum, Kraków 2017.

Hofmann D., Poronienie: zagrożenie i zaburzenia wczesnej cią̇y, przyczyny, rozpoznanie $i$ zapobieganie, tłum. J. Podgórski, Z. Tesarz, Państwowy Zakład Wydawnictw Lekarskich, Warszawa 1973.

Jakiel G., Robak-ChoŁubek D., Tkaczuk-WŁach J., Poronienia samoistne, „Przegląd Menopauzalny" 2006, nr 3, s. 191-193.

JAKOWICKI J.A., Genetyczne przyczyny utraty wczesnej ciąży, „Postępy Biologii Komórki” 2001, supl. nr 18, s. 25-32.

JASLOW C.R., Uterine factors, „Obstetrics and Gynecology Clinics of North America” 2014, nr 1(41), s. 57-86.

Johns G., Jauniaux E., Rozwój wczesnej ciąży, w: Postępowanie w powiklaniach wczesnej ciąży. Podręcznik, red. T. Bourne, G. Condous, thum. J. Bartosiewicz, Wydawnictwo Medipage, Warszawa 2007, s. 9-18. 
JóźWIK M., ŚLEDZIEWSKI A., Powikłania poronień samoistnych i sztucznych, w: Powikłania poronień samoistnych i sztucznych, Wydawnictwo Lekarskie PZWL, Warszawa 2002, s. 338-352.

Keirse M., Spitz B., Vandermeulen A., Jak sobie radzić z poronieniem, tłum. M. Wężkowska, Polskie Wydawnictwo Encyklopedyczne, Radom 2007.

Kwinecka-Dmitriew B., Zakrzewska M., Latos-Bieleńska A., Skrzypczak J., Częstość występowania aberracji chromosomowych $w$ materiale z poronień, „Ginekologia Polska” 2010, nr 12(81), s. 896-901.

LAChelin C.L., Poronienia, tłum. A. Kurczuk-Powolny, Wydawnictwo Prószyński i S-ka, Warszawa 1998.

Lewicka M., Sulima M., PYĆ M., STAWARZ M., Charakterystyka poronień i prawa przystugujace kobiecie po stracie dziecka, „Annales Academiae Medicae Stetinensis” 2013, nr 59, z. 1, s. 123-129.

MaLINOwSKi A., RADWAN M., Diagnostyka immunologiczna w poronieniach nawykowych: algorytm postępowania diagnostyczno-leczniczego z wykorzystaniem wyników badań własnych, „Perinatologia, Neonatologia i Ginekologia” 2011, nr 1(4), s. 27-36.

MALINOWSKI A., WILCZYŃSKI J.R., Immunologiczne mechanizmy utrzymania ciąży, „Ginekologia Praktyczna" 2003, nr 4(11), s. 47-56.

Malinowski A., Wilczyński J.R., Poronienia nawykowe, w: Patologia wczesnej ciąży, red. T. Paszkowski, IZT, Lublin 2004, s. 67-100.

Michalak M., Darmochwat-Kolarz D., Leszczyńska-Gorzelak B., Oleszczuk J., Przyczyny, diagnostyka i leczenie poronień nawykowych - część I, „Ginekologia i Położnictwo” 2011, nr 1(19), s. 15-30.

Michalak M., Darmochwal-Kolarz D., Leszczyńska-Gorzelak B., OleszczuK J., Przyczyny, diagnostyka i leczenie poronień nawykowych - część II, „Ginekologia i Położnictwo” 2011, nr 3(21), s. 9-26.

Norwitz E., Schorge J., Położnictwo i ginekologia w zarysie, red. nauk. tłum. B. Chazan, Wydawnictwo Lekarskie PZWL, Warszawa 2006.

Opala T., Woźniak J., RZYMSKi P., ChMAJ-WierzchowsKa K., WinconeK-Oberc U., WilcZaK M., Rola czynników immunologicznych w poronieniach nawykowych, „Ginekologia Polska” 2011, nr 5(11), s. 2-4.

PASSARGe E., Genetyka. Ilustrowany przewodnik, Wydawnictwo Lekarskie PZWL, Warszawa 2004.

Piotrowski J., Pielęgniarstwo w położnictwie i ginekologii. Podręcznik dla studentów wydziałów pielęgniarskich akademii medycznych, wyd. 2, Państwowy Związek Wydawnictw Lekarskich, Warszawa 1984.

Postępowanie w przypadku straty wczesnej ciązy. Wytyczne Royal College of Obstetricians and Gynaecologists., „Medycyna Praktyczna - Ginekologia i Położnictwo” 2007, nr 2, s. 19-37.

Radomański T., Paszkowski T., Wrona W., Poronienie septyczne, w: Patologia wczesnej cia$\dot{z} y$, red. T. Paszkowski, IZT, Lublin 2004, s. 101-107.

Rekomendacje Polskiego Towarzystwa Ginekologicznego w zakresie wybranych patologii wczesnej ciązy oraz postępowania $w$ ciązy po zapłodnieniu in vitro, „Przegląd Menopauzalny” 2004, nr 6, s. 8-12.

Sikora J., BaKon I., DemBnicki T., Znaczenie czynników infekcyjnych w poronieniach i porodzie przedwczesnym, „Ginekologia i Położnictwo” 2011, nr 2(20), s. 35-46. 
SIKORA J., Znaczenie czynników mikrobiologicznych w poronieniach i porodzie przedwczesnym standard postępowania diagnostyczno-leczniczego, „Perinatologia, Neonatologia i Ginekologia" 2011, nr 1(4), s. 37-43.

Silva A., Milio L., Schorzenia endokrynologiczne w ciąży, w: Podręcznik ginekologii i położnictwa Johns Hopkins, red. K.B. Fortner, L.M. Szymanski, H.E. Fox, E.E. Wallach, Wydawnictwo MediPage, Warszawa 2012, s. 223-241.

SKRZYPCZAK J., Badania diagnostyczne u kobiet z wczesnymi utratami ciąz, w: Położnictwo, t. 4. Diagnostyka biofizyczna i biochemiczna w medycynie perinatalnej, red. G. Bręborowicz, M. Wielgoś, Wydawnictwo Lekarskie PZWL, Warszawa 2012, s. 365-374.

SkrzypCZak J., Pisarski T., Poronienie, w: Polożnictwo i ginekologia. Podręcznik dla studentów, red. T. Pisarski, Państwowy Zakład Wydawnictw Lekarskich, Warszawa 1991, s. 196-204.

Skrzypczak J., Poronienie, w: Ciaża wysokiego ryzyka, red. G.H. Bręborowicz, wyd. 3, Ośrodek Wydawnictw Naukowych, Poznań 2010, s. 97-120.

SKRZYPCZAK J., Standardy postępowania w nieprawidtowościach pierwszego trymestru ciaży, w: Poronienia nawracajace, red. J. Skrzypczak, Wydawnictwo Lekarskie PZWL, Warszawa 2011, s. 197-209.

Stonehouse A., Sutherland B., Po poronieniu, Państwowy Zakład Wydawnictw Lekarskich, Warszawa 1992.

Stovall T.G., Poronienie i ciąża pozamaciczna, w: Ginekologia, t. 2, red. J.S. Berek, E. Novak, thum. A. Czekierdowski, Wydawnictwo Medipage, Warszawa 2008, s. 663-693.

StUPAK A., KWAŚNIEWSKA A., Aktualne rekomendacje postępowania w poronieniu, „Wiadomości Lekarskie" 2015, nr 1(68), s. 79-87.

SZAŁEK E., GRZEŚKowiak E., Bezpieczeństwo farmakoterapii w okresie ciąży, „Farmacja Współczesna" 2008, nr 1, s. 109-115.

Szkodziak P., Paszkowski T., Paszkowski M., Radomański T., Poronienie, w: Polożnictwo, t. 2. Medycyna matczyno-płodowa, red. G.H. Bręborowicz, T. Paszkowski, Wydawnictwo Lekarskie PZWL, Warszawa 2012, s. 1-9.

ŚmiertKa W., Boj J., Poronienie, „Nowa Klinika” 1999, nr 6 (12), s. 1231-1232.

TOwner D., Implikacje genetyczne utraty ciązy, w: Położnictwo, red. D.R. Mishell, P.F. Brenner, tłum. B. Kamiński, wyd. 1, Wydawnictwo Alfa-Medica Press, Bielsko-Biała 1995, s. 430-436.

\section{PORONIENIE KLINICZNE JAKO NIEPOWODZENIE POŁOŻNICZE RODZICÓW - ASPEKT BIOMEDYCZNY}

\section{STRESZCZENIE}

Poronienie kliniczne jest patologią rozpoznanej ciąży dokonującą się przed dopełnieniem 22. tygodnia rozwoju prenatalnego dziecka o wadze poniżej $500 \mathrm{~g}$. Co czwarta kobieta doświadcza straty prokreacyjnej w wyniku poronienia klinicznego. Ten rodzaj niepowodzenia położniczego jest warunkowany wieloczynnikową etiologią o podłożu genetycznym, immunologicznym, endokrynologicznym, morfologicznym i anatomicznym, infekcyjnym, jatrogennym. Fizjologia poronienia pozwala dokonać typologii jego postaci klinicznych i na tej podstawie wyróżnić: poronienie zagrażające, poronienie zaczynające się, poronienie $\mathrm{w}$ toku, poronienie kompletne, poronienie niekompletne, poronienie zatrzymane, poronienie szyjkowe, poronienie gorączkowe i poronienie 
septyczne. Częstotliwość poronień ciąż klinicznie rozpoznanych wskazuje na niepowodzenia występujące epizodycznie oraz w sposób nawracający. W pracy podjęto próbę konceptualizacji poronienia klinicznego i przedstawienia jego syntetycznej charakterystyki w oparciu o przegląd literatury przedmiotu przez zastosowanie metody desk research. W wyniku przeprowadzonych analiz wskazano na potrzebę włączenia problematyki strat prokreacyjnych do programów nauczania przedmiotu wychowania do życia w rodzinie i szeroko pojętej edukacji prenatalnej jako formy psychospołecznej profilaktyki niepowodzeń położniczych, jak również w celu dostarczenia wiedzy niezbędnej do konstruktywnego przepracowania straty prokreacyjnej oraz kształtowania pozytywnych postaw społecznych wobec rodziców będących w żałobie po poronieniu dziecka.

Słowa kluczowe: poronienie kliniczne; strata ciąży; etiopatogeneza; epidemiologia; dzieci prenatalne. 